Ks. Michał Drożd $\dot{z}$

\title{
JAN PAWEŁ II - ODSŁONY PIĘKNA ŚWIĘTOŚCI
}

\section{Wstęp}

Przed kilkunastu laty obiegła świat wiadomość, że jakiś człowiek próbował rozbić Pietę watykańską, arcydzieło sztuki dłuta Michała Anioła, przedstawiające Matkę Bolesną trzymającą na kolanach martwe ciało Syna. Tysiące i miliony ludzi zachwycało się i zachwyca pięknem Madonny, dziełem ludzkiego geniuszu. A jednak znalazł się ktoś, kto chciał zniszczyć to piękno, dzieło ludzkich rąk i artyzmu. Jest takie piękno, które trzeba chronić: to piękno ludzkich serc, piękno prawdziwego człowieczeństwa, piękno ludzkiej duszy, piękno świętego człowieka, promieniującego świętością.

„Święci nie przemijają, święci żyją świętymi, święci wołają o świętość” ${ }^{1}$ - mówił do nas św. Jan Paweł II w Starym Sączu. Czuję się zaszczycony i onieśmielony, gdy piszę o pięknie świętości w kontekście refleksji nad dziedzictwem tego wielkiego i dobrego człowieka. Czynię to jednak z ogromną pokorą wobec wielkości Jana Pawła II, którego wielkość i promieniowanie świętością wyzwala z nas dobro i pozwala nam pragnąć świętości.

Im więcej upływa czasu od przejścia Jana Pawła II do domu Ojca, im więcej czasu mija od jego beatyfikacji i kanonizacji, tym mocniej ujawnia się bogactwo jego świętości i tym mocniej wybrzmiewa świadectwo jego wiary, nadziei i miłości. Prosta obserwacja mówi, że nikt z nas nie byłby dziś taki, jaki jest, bez owoców jego nauczania, pielgrzymowania i niepowtarzalnego świadectwa. Osoba i dzieło Jana Pawła II są swoistym fenomenem w dzisiejszym świecie. Fenomenem osobowym, w znaczeniu ideału osobowego, jest najpierw sam Jan Paweł II Wielki - świadek wiary, pielgrzym nadziei, człowiek niosący wszystkim dobro i miłość. Trzeba mieć dużo taktu i delikatności i pokory, aby mówić o przesłaniu Jana Pawła II. Papież jest na pewno jednym z najwybitniejszych myślicieli naszych czasów. Jest heroicznym świadkiem wiary, nadziei i miłości. Jego osoba

1 Jan Paweł II, Homilia w czasie Mszy św. odprawionej w Starym Sączu, Stary Sącz, 10 czerwca 1999, nr 1. 
i dzieło wymyka się też kryteriom badawczym, gdyż jest on prorokiem naszych czasów, prawdziwym autorytetem. Dlatego mówienie o autorytecie jest mówieniem o człowieku dobrym, człowieku nadziei. Podstawowym warunkiem autorytetu jest życie w prawdzie. Być autorytetem - to być za autorytet uznanym. Autorytet ma to do siebie, że jest przede wszystkim wartością dla innych i to jest istota autorytetu moralnego: być dla innych wartością w dobru i prawdzie.

Jan Paweł II fascynował świat swoją osobą. Jego głębokie umiłowanie Boga, umiłowanie prawdy, ewangeliczna prostota stały się źródłem szacunku, jaki zdobył także w świecie mediów. Było tak i wtedy, gdy nie szczędził krytyki pod ich adresem, bo sprzeniewierzały się prawdzie, dobrym obyczajom i godziły w podstawowe wartości ogólnoludzkie. Zawsze jednak zachęcał dziennikarzy do wsłuchiwania się w problemy człowieka i do obrony jego praw, do bycia rzecznikami spraw ludzkich, przekazywania prawdy o człowieku i jego godności. Był głęboko przekonany, że otwarcie Kościoła na media przyniesie dobre owoce. W swoim Testamencie Jan Paweł II napisał już w 1980 roku takie słowa: „Przyjmując już teraz tę śmierć, ufam, że Chrystus da mi łaskę owego ostatniego Przejścia, czyli Paschy. Ufam też, że uczyni ją pożyteczną dla tej największej sprawy, której staram się służyć: dla zbawienia ludzi, dla ocalenia rodziny ludzkiej"2. Patrząc na to wydarzenie z perspektywy czasu można powiedzieć, że jego odejście było Przejściem, które dokonało się na oczach świata dzięki pośrednictwu mediów. I w ten sposób stało się pożyteczne dla całego świata, stało się źródłem dobra i promieniuje na nas pięknem świętości. O jakim pięknie jest mowa? W starożytności wiązano je przede wszystkim z ideą dobra, duchowością, moralnością, myślą i rozumem; utożsamiano je wtedy z doskonałością jako warunkiem piękna i ludzkiej twórczości na najwyższym poziomie. Nad pięknem w blasku prawdy zastanawia się św. Augustyn, który pisząc Wyznania, mówi o Bogu odkrywanym w sobie: „Późno Cię umiłowałem, Piękności tak dawna a tak nowa, późno Cię umiłowałem. W głębi duszy byłaś, a ja się błąkałem po bezdrożach i tam Ciebie szukałem, biegnąc bezładnie ku rzeczom pięknym, które stworzyłaś”3 ${ }^{3}$. Piękno, podobnie jak i prawda, i dobro, przynależy do podstawowych wartości uniwersalnych, do uniwersaliów. Zachowanie piękna człowieczeństwa było podstawową troską Jana Pawła II, troską uwidacznianą w jego twórczości poetyckiej i dramaturgicznej, w jego dziełach filozoficzno-etycznych, ale przede wszystkim w jego pięknym życiu, w jego działalności i nauczaniu. Kilka aspektów tej troski chcę przestawić w moich refleksjach.

2 Jan Paweł II, Testament, 24.02-1.03.1980 r., Watykan 2005.

3 Św. Augustyn, Wyznania, przeł. Z. Kubiak, Warszawa 1982, Ks. 10, s. 213. 


\section{Świętość w odsłonach dobrego człowieka}

Karol Wojtyła powtarzał, że człowiek jest piękną istotą, jeśli naprawdę jest człowiekiem, nawiązując tym samym do starożytnych myślicieli, poetów - Menandra czy Terencjusza - czy też do myśli Arystotelesa. Troska Jana Pawła II, by zachować żywe piękno, to troska o to, by zachować piękno człowieczeństwa. Nie dziwi więc fakt, że w swojej pierwszej encyklice Redemptor hominis ${ }^{4}$ Jan Paweł II odsłania istotę człowieka w świetle prawdy, w świetle dobra, w świetle miłości. Można powiedzieć, że piękno - należące do uniwersaliów - jest jakimś koniecznym „tworzywem”, „formą”, w którą „ubierają się” prawda, dobro i miłość. Piękno nabiera wymiaru antropologiczno-etycznego, połączonego z wymiarem estetycznym. Samo piękno w oderwaniu od prawdy i dobra de facto przestaje „być piękne”. Stąd mówi się już od czasów Platona, że piękno jest ideą, wartością, prowadzącą do dobra i prawdy. Wszelki sens przygody z pięknem polega zatem na otwarciu przed człowiekiem bardziej zasadniczego horyzontu - horyzontu dobra. A ten horyzont jest horyzontem etyki. Prawdę tę głęboko wyraża potoczne doświadczenie, które mówi, że ktoś jest „dotknięty pięknem do żywego”, to znaczy, że jest poruszony przez piękno w stronę dobra.

Gdy idziemy tropem myśli Jana Pawła II, interesuje nas właśnie owo „dotknięcie pięknem w stronę dobra”, które objawia piękno człowieczeństwa. Piękną istotą jest człowiek, jeśli naprawdę jest człowiekiem. Jan Paweł II był i jest mistrzem w odsłanianiu oblicza pięknego człowieczeństwa w każdym z nas. To była sztuka, zdolność i wielkie dzieło Jana Pawła II: wyzwalanie dobra w człowieku, troska o piękno człowieczeństwa we wszystkich jego wymiarach, co widzimy na przykład w jego dziele Miłość $i$ odpowiedzialność ${ }^{5}$, w którym pokazuje piękno przyjaźni, miłości narzeczeńskiej, miłości małżeńskiej i rodzinnej, czy w dziele Dar i Tajemnica ${ }^{6}$, kiedy mówi o pięknie życia kapłańskiego. W świadectwie życia i nauczaniu Jana Pawła II człowiek święty to przede wszystkim człowiek dobry.

\section{Człowiek dobry - po pierwsze - to ten, kto ma świadomość bycia czło-} wiekiem. Nie jest ani zwierzęciem, ani aniołem - jest człowiekiem. Jest to człowiek nieustannie doskonalący siebie, człowiek, który ma w sobie ogromny potencjał dobra, które musi i powinien wyzwalać, by w pełni być człowiekiem ${ }^{7}$. Bądź dobrym człowiekiem, czyli stań się tym, kim jesteś. Piękny jest człowiek, jeśli jest prawdziwym człowiekiem. Życie w blasku prawdy o sobie, w prawdzie o swojej godności i wartości, życie w prawości sumienia, życie w odpowiedzialności

4 Por. Jan Paweł II, Enc. Redemptor hominis, Watykan 1979 [dalej: RH].

5 K. Wojtyła, Miłość i odpowiedzialność (Człowiek i moralność, 1), Lublin 2001.

6 Jan Paweł II, Dar i Tajemnica, Kraków 2011.

7 Por. RH 8. 
za siebie i innych: ileż razy te myśli niestrudzenie kierował do nas Jan Paweł II. Prawdziwy człowiek to prawy człowiek: prawość to odpowiedzialność za człowieczeństwo. Prawość jest niezbędnym warunkiem wszelkiej odpowiedzialności, a przede wszystkim warunkiem umiejętnego dostrzegania i odkrywania piękna dobrego i prawdziwego człowieczeństwa.

2. Po drugie - człowiek dobry to ten, kto jest człowiekiem prawego sumienia. Dlatego Jan Paweł II tak mocno wołał o ludzi sumienia. W słynnym przemówieniu w Skoczowie papież mówił: „Nasz wiek XX był okresem szczególnych gwałtów zadawanych ludzkim sumieniom. W imię totalitarnych ideologii miliony ludzi zmuszano do działań niezgodnych z ich najgłębszymi przekonaniami"s. I tak się rodziło zło. Dobro wypływa z prawego sumienia, które wskazuje na dobro i do dobra prowadzi. „Prawdziwa odnowa człowieka i społeczeństwa dokonuje się zawsze za sprawą odnowy sumień”.

\section{Po trzecie - człowiek dobry to człowiek, który ma świadomość prymatu wartości moralnych nad wszelkimi innymi wartościami.}

Dobroć, poszanowanie prawdy i pokora stoją ponad geniuszem, mądrością, kwitnącym zdrowiem - pisze Dietrich von Hildebrand - To, co się dokonuje i olśniewa nas w akcie szczerego przebaczenia, wielkodusznego wyrzeczenia lub w akcie bezinteresownej żarliwej miłości jest bardziej znaczące, ważniejsze i trwalsze od innych wartości tkwiących w kulturze. Wartości moralne są węzłowym problemem świata; brak moralnych wartości jest największym złem, gorszym niż cierpienie, choroba, śmierć, gorszym niż upadek kwitnących kultur ${ }^{10}$.

\section{Po czwarte - człowiek dobry to człowiek kultury, tzn. urzeczywistniający} kulturę zgodnie z naturą człowieczeństwa. Człowiek tworzy kulturę, wyraża się w niej, ale nie jest tylko dzieckiem kultury, która może być także przestrzenią zła.

Nie można zaprzeczyć - pisze Jan Paweł II w Veritatis splendor - że człowiek istnieje zawsze w ramach określonej kultury, ale prawdą jest też, że nie wyraża się on cały w tej kulturze. Zresztą sam fakt rozwoju kultur dowodzi, że w człowieku jest coś, co wykracza poza kulturę. To „coś” to właśnie ludzka natura: to ona jest miarą kultu-

8 Jan Paweł II, Homilia podczas Mszy św. na wzgórzu Kaplicówka w Skoczowie, 12 maja 1995, nr 3.

9 Jan Paweł II, Odnowa człowieka i społeczeństwa dokonuje się za sprawa sumień. Przemówienie z dnia 19 lutego 1998, nr 2, www.opoka.org.pl/biblioteka/W/WP/jan_pawel_ii/ przemowienia/bpi_pl3_1998.html (2015).

10 D. von Hildebrand, Prawość, „W drodze” (1973) nr 1, s. 115-116. 
ry i to dzięki niej człowiek nie staje się więźniem żadnej ze swych kultur, ale umacnia swoją osobową godność, żyjąc zgodnie z głęboką prawdą swojego bytu"11.

Prawda o człowieczeństwie odsłania nam wymiar dobra, wpisanego w sens ludzkiego życia. Odkrywanie tego dobra w prawdzie o sobie jest zadaniem każdego człowieka, który w ten sposób tworzy kulturę i w niej się wyraża.

5. Po piąte - człowiek dobry to człowiek odpowiedzialny przed własnym sumieniem i przed innymi ludźmi, a także przed Bogiem ${ }^{12}$. Prawość to odpowiedzialność za dobro - pisze Hildebrand ${ }^{13}$. Prawość jest niezbędnym warunkiem wszelkiej odpowiedzialności, a przede wszystkim warunkiem umiejętności dostrzegania wartości. Prawość jest również źródłem szacunku dla obiektywnie zobowiązujących wymagań płynących od wartości i ku wartościom, ku dobru.

6. Po szóste - człowiek dobry cieszy się życiem, odkrywa jego piękno i sens mimo trudności i problemów, jakie ono niesie. Jakże wymowne są pod tym względem słowa Jana Pawła II, schorowanego, cierpiącego człowieka, który pod koniec swojego życia pisał: „mimo ograniczeń mego wieku bardzo wysoko cenię sobie życie i umiem się nim cieszyć. Dziękuję za to Bogu. [...] Zarazem jednak głębokim pokojem napełnia mnie myśl o chwili, w której Bóg wezwie mnie do siebie - z życia do życia"14.

\section{Odkrywać piękno człowieka}

Człowiek może w rozmaity sposób być piękny, być nosicielem piękna, być jego podmiotem, i różnie też może objawiać piękno. Na przykład - człowiek, którego widzę, jest piękny całym swym wyglądem, chociaż jest bardzo skromnie ubrany; jest piękny spojrzeniem, swobodą ruchów, np. w tańcu; piękny wrażliwością na świat, piękną mową, smutkiem, radością, zamyśleniem, płaczem, wewnętrznym zdziwieniem, pokorą, elegancją stroju itp. Piękno odsłaniając się, odsłania od samego początku człowieka, a przede wszystkim - jak mówi od wieków filozofia nie tylko chrześcijańska - odsłania jego wnętrze, jego duszę. Odkrywając zaś w rozmaity sposób duszę człowieka, próbujemy odkrywać ogromną tajemnicę Bożego obrazu w człowieku. Dla Karola Wojtyły odkrywanie piękna, prawdy i dobra jest zadaniem, które wręcz fascynuje go przez całe życie. Wie o tym od

11 Jan Paweł II, Enc. Veritatis splendor, Watykan 1993, nr 53 [dalej: VS].

12 Por. szerzej: A. Drożdż, Fundamentalne przestrzenie odpowiedzialności ludzkiej, [w:] Jak żyć odpowiedzialnie w nieodpowiedzialnym świecie?, red. A. Wuwer, Katowice-Piekary Śląskie 2007, s. 68-81.

13 Por. D. von Hildebrand, Prawość, art. cyt., s. 122.

14 Jan Paweł II, List do ludzi w podeszłym wieku, Watykan 1999, nr 17. 
najmłodszych lat. Myśli o Bogu i człowieku kategoriami piękna osobowego. Młody Wojtyła w dramacie Brat naszego Boga wkłada w usta Adama Chmielowskiego słowa o tym, że sama inteligencja nie wystarcza ${ }^{15}$, że potrzeba miłości. Trzeba szukać czegoś więcej. Chmielowski jako artysta malarz szuka piękna. I co znajduje? Na ciemnej ulicy znajduje pod latarnią człowieka. W tym biedaku odkrywa niepowtarzalne piękno, które - jak to określa - jest dla niego „drogą oczyszczenia", gdy po doświadczeniach z biedakami podnoszonymi z ulicy staje przy sztalugach malowanego właśnie obrazu Ecce Homo (Oto człowiek). Jak Wojtyła pisze w dramacie, „Adam pozostał sam i zatrzymując wzrok na obrazie mówi bardzo wolno: «Wyniszczyli Cię [...]; Przy tym pozostałeś piękny; Najpiękniejszy z synów ludzkich; Takie piękno nie powtórzyło się już nigdy później; O, jakież trudne piękno, jak trudne; Takie piękno nazywa się Miłosierdzie»"16.

Ta młodzieńcza wrażliwość Wojtyły na piękno człowieka dobrego, miłosiernego trwała i potęgowała się przez całe jego życie. Nie dziwi więc fakt, że Jan Paweł II szukał piękna człowieka wszędzie: w slumsach Ameryki Południowej, gdy ku przerażeniu zdumionych dziennikarzy przytula chorych na AIDS, gdy samotnie rozmawia w celi z Ali Agcą, kiedy pisze encyklikę o Odkupicielu człowieka ${ }^{17}$, kiedy przytula dzieci i gdy schorowany wychodzi do młodzieży i nie może im podziękować nawet jednym słowem, bo nie ma już sił, by mówić: oto człowiek! Piękno „bycia człowiekiem” pojawia się w niemal wszystkich spotkaniach Jana Pawła II z młodzieżą. „Miej serce i patrzaj w serce”! - mówił Jan Paweł II do młodzieży akademickiej w Warszawie, cytując Mickiewicza. „Człowieka [...] trzeba mierzyć miarą sumienia, miarą ducha"18.

Streszczeniem wielkiego papieskiego wykładu na temat piękna duchowego jest jego przemówienie do ludzi kultury w dniu 13 czerwca 1987 w Warszawie w kościele Świętego Krzyża:

Waszym powołaniem, drodzy Państwo, jest piękno. Tworzyć przedmioty piękne. Wywoływać piękno w wielorakiej materii ludzkiej twórczości: w materii słów i dźwięków, w materii barw i tonów, w materii rzeźbiarskich czy architektonicznych brył, w materii gestów, którymi wyraża się i przemawia to najszczególniejsze tworzywo świata widzialnego, jakim jest ludzkie ciało. „Cóż wiesz o pięknem?.. Kształtem jest Miłości”. A zatem: czy nie pozostaje ono w jakimś intymnym, bardzo rzeczywistym związku z Tym, który umiłował do końca? Który objawił

15 Por. K. Wojtyła, Brat naszego Boga, [w:] K. Wojtyła, Poezje i dramaty, Kraków 1987, s. $144 n$.

16 K. Wojtyła, Brat naszego Boga, dz. cyt., s. 160.

17 Por. RH.

18 Jan Paweł II, Przemówienie do młodzieży akademickiej zgromadzonej przed kościołem św. Anny w Warszawie, 3 czerwca 1979 roku, nr 2. 
definitywną miarę miłości w dziejach człowieka i świata? A zatem: czy to piękno, które jest waszym powołaniem, waszym trudem [...] - nie pozostaje w ukrytej, niemniej realnej więzi z Odwiecznym Pięknem i Odwieczną Miłością?”19.

„Cóż wiesz o Pięknem?.. Kształtem jest Miłości”"20.

\section{Świętość w pięknie wartości}

Jan Paweł II jako etyk i humanista wysokiej klasy wie dobrze, że człowiek nie może żyć bez wartości. Wartość - to coś cennego. A wartości etyczne są z gruntu wartościami osobowymi. Bez nich człowiek nie może objawiać się jako człowiek. Wartości są różne. Są wartości witalne, konieczne do życia, są wartości ekonomiczne, rodzinne, ojczyźniane, estetyczne itp. Wartością jest życie ludzkie, wartością jest młodość, wartością jest człowiek, wartością jest miłość. To są z punktu widzenia aksjologii różne wartości. Jan Paweł II próbuje jednak często łączyć wartości etyczne, ontyczne i estetyczne, używając pojęcia „piękna”, mówiąc „piękno życia”, „piękno młodości”, „piękno człowieka”, „piękno miłości”. W ten sposób podkreśla ważność tych wartości i nadaje pięknu wymiar etyczny. W bogatym nauczaniu Jana Pawła II piękno opisywane jest za pomocą takich wartości, jak: szczęście, dojrzałość, doskonałość, uczciwość, ład moralny, świętość. Wartości te są nie do pomyślenia w oderwaniu od przeżywanego osobowo piękna, od doświadczenia piękna własnego człowieczeństwa.

Jan Paweł II mówi o „pięknie szczęścia”, którego słusznie pragnie każdy człowiek. Jest to „piękno uczestniczenia w prawdziwych wartościach prawdy, dobra i piękna”. One koncentrują się wokół człowieka i konstytuują jako osobę każdego człowieka: dzieci, rodziców, młodzież, ludzi zdrowych i chorych, twórców kultury, męczenników naszych czasów, biednych i bogatych. W Liście do młodych papież pisze między innymi o pięknie młodości, nazywając młodość „bogactwem”: chodzi o „piękno mądrego zagospodarowania młodości”"21. Chodzi tu o odpowiedź, która dotyczy całego życia człowieka, który został stworzony do szczęścia. W słynnym przemówieniu do młodzieży na Westerplatte w dniu 18 czerwca 1987 roku ojciec święty mówi o najważniejszych wartościach, które decydują o szczęściu człowieka:

19 Jan Paweł II, Przemówienie do przedstawicieli świata kultury zgromadzonych w kościele Świętego Krzyża w Warszawie, 13 czerwca 1987, nr 6.

${ }_{20}$ C. K. Norwid, Promethidion. Rzecz w dwóch dialogach z epilogiem, dialog Bogumit, Warszawa 1900, III, 431.

21 Jan Paweł II, List do młodych całego świata Parati semper, Watykan 1985, nr 3. 
Chodzi bowiem o wartości trwałe i niezmienne. [...] Każdy z was, młodzi Przyjaciele, znajduje też w życiu jakieś swoje „Westerplatte”. Jakiś wymiar zadań, które trzeba podjąć i wypełnić. Jakąś słuszną sprawę, o którą nie można nie walczyć. Jakiś obowiązek, powinność, od której nie można się uchylić. [...] Jakiś porządek prawd i wartości, które trzeba „utrzymać” i „obronić” ${ }^{22}$

Taka troska o szczęście, szczęście własne i drugiej osoby, kosztuje, bo wszystko, co jest cenne, musi kosztować. Wszystko, co piękne i wartościowe, musi kosztować.

W nauczaniu Jana Pawła II znaczący jest motyw „piękna dojrzałości życiowej”. W Częstochowie, podczas pożegnalnego przemówienia podczas spotkania z młodzieżą, Jan Paweł II przypomina podstawową zasadę dojrzewania do doskonałości. Pojęcie piękna i pojęcie doskonałości moralnej ściśle się ze sobą wiążą. Papież streszcza to tak:

Wzrastać, dojrzewać: oto zadanie młodego człowieka. W sferze biologicznej zastój, brak rozwoju jest znakiem rozpoczynającej się starości. To samo prawo odnosi się do życia duchowego. Różnica jest tylko jedna: duch nie zna biologicznych ograniczeń wzrostu. I właśnie dlatego nie podlega procesowi starzenia się. Oto zadanie, jakie mamy: „wzrastajcie jako osoby, rozwijajcie talenty właściwe dla ciała i dla duszy, wzrastajcie jako ludzie w dążeniu do duchowego piękna"23.

W aspekcie piękna aksjologicznego możemy mówić za Janem Pawłem II także o „pięknie uczciwości”. W dniu 7 czerwca 1991 w Płocku papież wyraźnie mówił o nim:

I bardzo też uważajmy, żebyśmy się nie stali społeczeństwem, w którym wszyscy wszystkim czegoś zazdroszczą. Przywracajmy blask naszemu pięknemu słowu uczciwość: uczciwość, która jest wyrazem ładu serca, uczciwość w słowie i czynie, uczciwość w rodzinie i stosunkach sąsiedzkich, w zakładzie pracy i w ministerstwie, w rzemiośle i handlu, uczciwość, po prostu uczciwość w całym życiu. Jest ona źródłem wzajemnego zaufania, a w następstwie jest także źródłem pokoju społecznego i prawdziwego rozwoju ${ }^{24}$.

22 Jan Paweł II, Homilia w czasie liturgii słowa skierowana do młodzieży zgromadzonej na Westerplatte, 12 czerwca 1987, nr 8.

${ }^{23}$ Jan Paweł II, Przemówienie pożegnalne do młodzieży w Częstochowie, 15 sierpnia 1991, nr 1.

24 Jan Paweł II, Homilia podczas Mszy św. w Płocku, 7 czerwca 1991, nr 4. 
Pojęcie piękna moralnego jest w nauczaniu Jana Pawła nieodłączne od pojęcia „ładu” - w tym „ładu moralnego”. Jest to „piękno czystych sumień”. W dniu 22 maja 1995 w Skoczowie ojciec święty mówił o potrzebie ludzi sumienia:

Dlatego Polska woła dzisiaj nade wszystko o ludzi sumienia! Być człowiekiem sumienia, to znaczy przede wszystkim w każdej sytuacji swojego sumienia słuchać i jego głosu w sobie nie zagłuszać, choć jest on nieraz trudny i wymagający; to znaczy angażować się w dobro i pomnażać je w sobie i wokół siebie, a także nie godzić się nigdy na zło, w myśl słów św. Pawła: „Nie daj się zwyciężyć złu, ale zło dobrem zwyciężaj!”25.

Zwyciężanie dobrem jest miarą sumienia, jest miarą piękna sumienia, a tym samym piękna człowieka.

\section{Przekazywać piękno świętości}

Jan Paweł II wielokrotnie pokazywał, że mistrzami piękna duchowego są rodziny. Wiele razy mówi o pięknie macierzyństwa i ojcostwa. Warto zauważyć, że w bogatym papieskim nauczaniu słowo "piękno" może być zastępowane przez „godność" lub „świętość” i odwrotnie. To pokazuje, jak mocno świętość jest związana z godnością i pięknem duchowym człowieka. Już podczas pierwszej pielgrzymki - 5 czerwca 1979 roku w Gnieźnie - papież mówił:

Pragnę na tym miejscu oddać hołd polskiej matce, oddać hołd polskiej kobiecie w wymiarach tysiąclecia! Mówimy «Gniezno» - to znaczy «gniazdo»! Gniazdo narodu, kolebka. Nad kolebką zawsze pochyla się kobieta, matka. Pragnę oddać hołd polskim matkom na naszej ojczystej ziemi! ${ }^{26}$

Rezerwuarem piękna jest cała „tradycja chrześcijańska i narodowa”. W Kalwarii Zebrzydowskiej 7 czerwca 1979 roku Jan Paweł II mówił:

[...] te góry przyciągały ludzi [...]. Kalwaria ma w sobie coś takiego, że człowieka wciąga. Co się do tego przyczynia? Może i to naturalne piękno krajobrazu, który stąd się roztacza u progu polskich Beskidów [...]. Zapraszają nas one, aby tu wrócić na nowo - i na nowo się w nie zagłębić. $W$ tych tajemnicach wyrażone jest zarazem

25 Jan Paweł II, Homilia podczas Mszy św. na wzgórzu Kaplicówka w Skoczowie, 12 maja 1995 , nr 3.

26 Jan Paweł II, Słowo do wiernych zgromadzonych na wzgórzu Lecha w Gnieźnie, 3 czerwca 1979 roku, nr 1. 
wszystko, co składa się na nasze ludzkie, ziemskie pielgrzymowanie, na piękno „dróżek” dnia powszedniego. Co za wspaniała zresztą nazwa - „dróżki”, trudno znaleźć w innych językach jakiekolwiek słowo, które by temu odpowiadało ${ }^{27}$.

Kilka dni później w Nowym Targu papież rozwija motyw „piękna wypoczynku” i wyjaśnia: „Odpocząć - napisał kiedyś Norwid - to znaczy "począć na nowo»”28.

Ważnym, narodowym źródłem „odnowy” i „piękna duchowego” jest Jasna Góra. Podczas trwającego jeszcze stanu wojennego, w przemówieniu na Karlsplatz w Wiedniu dnia 12 września 1983 roku Jan Paweł II przypominał, iż źródłem duchowych mocy jest Jasna Góra:

Jasna Góra jest bowiem znakiem i źródłem tych wartości [...], które kształtują ducha i serca ludzi żyjących na naszej ziemi; które gasnące oczy zapalają nadzieją, które porażkę nawet zmieniają w zwycięstwo. Nasz poeta, wyznając w swoim wierszu Boga gospodarzem świata, dodaje z wielką prostotą: „A czy wiecie, gdzie byłem, gdzie się tego uczyłem? Częstochowskie ja dziecię, stamtąd idę piechotą, choć daleko, z ochotą!" (C. K. Norwid) ${ }^{29}$.

Jan Paweł II - przywołując największych myślicieli i najpiękniejsze postaci z naszej historii: Długosza, św. Jadwigę, św. Kingę, Norwida, Mickiewicza i Krasińskiego, ks. Jerzego Popiełuszkę i kard. Stefana Wyszyńskiego, dawnych i współczesnych męczenników w każdym zakątku naszej ziemi - uczy nas nie tylko wrażliwości na wszelkie odsłony piękna, ale i o rzeczpospolitej pięknych dusz.

Oddzielną sprawą jest papieskie „piękno wspomnień”. Prawie nikt o tym nie pisze - a szkoda. Wszystkie odsłony piękna wspomnień o ludziach, miejscach, zdarzeniach stawia Jan Paweł II w perspektywie „piękna wieczności”. Świadczy o tym między innymi fragment bardzo osobistego przemówienia w Wadowicach w dniu 16 czerwca 1999 roku:

Z wielkim wzruszeniem patrzę na to miasto lat dziecięcych, które było świadkiem mych pierwszych kroków, pierwszych słów i tych - jak mówi Norwid - „pierwszych ukłonów”, co są „jak odwieczne Chrystusa wyznanie: Bądź pochwalony! ” (por. Moja piosenka). Miasto mojego dzieciństwa, dom rodzinny, kościół parafialny, kościół mojego chrztu św. [...] Pragnę wejść w te gościnne progi, na nowo ukłonić się rodzinnej

27 Jan Paweł II, Przemówienie do pielgrzymów zgromadzonych w Sanktuarium Matki Bożej w Kalwarii Zebrzydowskiej, 7 czerwca 1979 roku, nr 2.

28 Jan Paweł II, Homilia w czasie Mszy św. w Nowym Targu, 8 czerwca 1979 roku, nr 5.

29 Jan Paweł II, Przemówienie na Karlsplatz w Wiedniu: „Bądźcie dojrzali dojrzałościa wiary i mocni moca ducha”, Wiedeń, 12 września 1983 roku, nr 6. 
ziemi i jej mieszkańcom [...]. A dom był tutaj, za moimi plecami, przy ulicy Kościelnej. A kiedy patrzyłem przez okno, widziałem na murze kościelny zegar słoneczny i napis: „Czas ucieka, wieczność czeka” ${ }^{30}$.

\section{Kanonizacja Jana Pawła II jako odsłona świętości}

Na koniec, korzystając z przyczynkowej analizy programu kanału I Telewizji Polskiej w dniach 26 i 27 kwietnia 2014 roku, w przeddzień i w dniu kanonizacji Jana Pawła II, chcę pokazać przykład medialnych poszukiwań i prób pokazania jego świętości. Moja analiza jest próbą opisania, w jaki sposób te przekazy mierzą się ze świętością Jana Pawła II. Próbuję w nich odkrywać niektóre medialne odsłony świętości Jana Pawła II, w których został on ukazany jako autorytet duchowy, człowiek nadziei, człowiek dobry, człowiek dialogu itd. Obrazy te odsłaniają piękno i wartość ludzkiego życia w kontekście piękna duchowych wartości, które współtworzą wymiar świętości.

1. Świętość jako inna obecność. Świętość Jana Pawła ukazuje perspektywę jego nowej obecności, duchowej obecności w wielkim dziedzictwie, które pozostawił, ale również nowej obecności jako naszego orędownika u Boga, „Brata naszego Boga", który nadal jest $\mathrm{z}$ nami. Wymowna oprawa graficzna, wielokrotnie pokazywana pod znamiennym tytułem "Jestem z Wami”, wprowadzająca zarówno w sekwencje prezenterskie, jak i oddzielająca program papieski od całości programu, podkreślała nową formę obecności Jana Pawła II w perspektywie innej rzeczywistości. To była próba dotknięcia tajemnicy świętych obcowania w duchu chrześcijańskiej eschatologii. To pokazywanie nowego wymiaru obecności Jana Pawła II pośród nas jest także wyjątkowym fenomenem w mediach, ponieważ jej odkrywanie zakłada perspektywę wiary. Telewizja Polska pokazała w ten sposób nieprzemijającą wartość autorytetu Jana Pawła II, podkreślając przy tym prawdę, że prawdziwe autorytety „nie odchodzą”, są z nami. Jan Paweł II jest z nami nadal w innych wymiarach obecności.

2. Świętość Jana Pawła jako swoiste przeniesienie w wymiar ikoniczności. Telewizja, posługując się obrazem, pokazywała Jana Pawła II jako „osobową ikonę" na wzór obrazu kanonizacyjnego przejętego z beatyfikacji. Ten obraz utrwalany w przekazach telewizyjnych stanowił dopełnienie dzieła Jana Pawła II, jakby zamknięcie medialnej obecności Jana Pawła II pośród nas w ogromnej skali dziennikarskiego i organizacyjnego zaangażowania. Takie ujęcie było ze wszech miar słuszną formą ukazania tajemnicy świętości. Mogło też być jednak ostatnią medialną okolicznością zainteresowania osobą Jana Pawła II w takiej skali, co

30 Jan Paweł II, Przemówienie do mieszkańców Wadowic, 16 czerwca 1999 roku, nr 1. 
niestety się częściowo potwierdziło, a o czym pisze w swoim artykule zawartym w niniejszej publikacji prof. Teresa Sasińska-Klas, podkreślając że medialne zainteresowanie św. Janem Pawłem II w I rocznicę kanonizacji było już znacząco słabsze. To świadczy również o tym, że świętość Jana Pawła II, wyrażona w formie aureoli świętości, przeniosła go bardziej w przestrzeń sakralną, w której cieszy się ogromnym kultem i podziwem wiernych kosztem mniejszego zainteresowania w sferze społecznej, publicznej i medialnej. Jest to zjawisko, które stanowi wyzwanie dla mediów: w jaki sposób przekuć świętość Jana Pawła II na realia życia codziennego i przywrócić jego rolę w kształtowaniu cywilizacji miłości w życiu wspólnotowym i społecznym?

3. Świętość człowieka Bożego. Ten wymiar świętości był szczególnie widoczny w wypowiedziach gości programów informacyjnych i publicystycznych, świadectwach spotkań ludzi z Janem Pawłem, np. w świadectwie osobistego fotografa papieskiego Artura Mariego w programie Metr od świętości. Chociaż trudno tę moc i to promieniowanie ukazać medialnie, to jednak kanonizacja Jana Pawła ułatwiała sięganie do tego głębokiego wymiaru świętości, który jest oparty na wierze i modlitwie. Widzieliśmy obrazy papieża jako człowieka modlącego się, człowieka, który wytrwał do końca pomimo cierpień, człowieka, który się nie lęka pomimo wielu zagrożeń cywilizacyjnych. Takie świadectwo o Janie Pawle II daje kardynał Stanisław Dziwisz, który pisze: „W tym ostatnim momencie ziemskiej wędrówki ojciec święty stał się ponownie tym, kim był zawsze, człowiekiem modlitwy. Człowiekiem Bożym, głęboko zjednoczonym z Panem, dla którego modlitwa stanowiła nieprzerwanie fundament egzystencji”31.

4. Świętość człowieka nadziei. Kanonizacja z swej samej natury domagała się języka medialnego uwzględniającego perspektywę nadziei i eschatologii chrześcijańskiej. Redakcja katolicka Telewizji Polskiej, która koordynowała większość programów dotyczących kanonizacji, była przygotowana na to, by szukać takiego języka przekazu telewizyjnego, który dobrze wyrazi tajemnice wiary i świętości. Świętość jako wymierny znak innego życia rodzi nadzieję. Dlatego telewizyjne obrazy Jana Pawła, zwłaszcza wydobyte z archiwalnych nagrań jego słowa: „Nie lękajcie się”, tchnęły nadzieją. Zaangażowanie mediów w pokazanie jego świętości można odczytywać także jako ich odpowiedź na słowa Jana Pawła II z ostatniego listu apostolskiego poświęconego środkom społecznego przekazu Szybki rozwój, w którym mocno wybrzmiewają profetyczne słowa: skierowane do wszystkich „Nie lękajcie się mediów”, a do ludzi mediów katolickich - „Przekazujcie orędzie nadziei [...], zachowując stale żywą w tym świecie, który mija,

31 S. Dziwisz, Świadectwo, Warszawa 2007, s. 228. 
wieczną perspektywę Nieba, perspektywę, której żaden ze środków przekazu nie będzie mógł nigdy bezpośrednio osiągnąć"32.

5. Dobroć i miłość jako miara i znak świętości. Wiele wypowiedzi, programów, relacji podkreślało wymiar pięknego człowieczeństwa Jana Pawła II jako człowieka dobrego. Dobro przyciąga, fascynuje i pociąga. I taki wymiar świętości wyłania się z wielu świadectw ludzi, którzy chociażby na moment spotkali papieża w swoim życiu. Człowiek dobry niesie miłość i głosi miłosierdzie, żyje w blasku prawdy o sobie, o swojej godności i wartości, w prawości sumienia, odpowiedzialności za siebie i innych. Telewizja próbowała odsłaniać dobroć Jana Pawła II na wiele sposobów, np. w: obrazach jego otwartości dla innych, głoszonym orędziu miłosierdzia, szacunku dla ludzi, przyciąganiu ludzi do siebie dobrocią. Ten wymiar dobroci łączył obu papieży: Jana Pawła II i Jana XXIII, nazwanego już dawno Papieżem Dobroci. Ten wymiar dobroci obu świętych papieży telewizja próbowała pokazać szczególnie w relacjach z Watykanu i relacjach reporterskich z Polski, m.in. z Krakowa, Zakopanego czy Wadowic.

6. Świętość człowieka dialogu. Jan Paweł II żadnego człowieka nie traktował jako Obcego, ale zawsze jako siostrę lub brata w jednej rodzinie ludzkiej. Ten wymiar świętości wyrażający się poprzez otwartość i dialog był szczególnie widoczny podczas transmisji w tych rzeszach wiernych z całego świata, których twarze radosne, szczęśliwe, mówiły więcej niż jakikolwiek komentarz. Jan Paweł II bardzo często zaczynał swe przemówienia i spotkania z ludźmi od zwrotu: „bracia i siostry”. I nie był to w jego ustach zwrot wyłącznie grzecznościowy czy pusty, tradycyjny slogan, lecz swoiste credo antropologiczne, odwołujące się do uniwersalnego braterstwa wszystkich ludzi i miłości do każdego człowieka. Ten wymiar otwartości i dialogu był widoczny szczególnie w czasie transmisji mszy św. kanonizacyjnej i w programach Metr od świętości.

7. Świętość człowieka cierpienia. W programie Metr od świętości ${ }^{33}$ Arturo Mari opowiada o ciężkiej operacji, której został poddany z powodu problemów z kręgosłupem. Jak zawsze w trudnej chwili zwrócił się w modlitwie do papieża, prosząc tylko o jedno: by w razie niepowodzenia pozwolił mu odejść we śnie. Telewizja przywołała ze swoich archiwów wiele obrazów cierpiącego papieża, zwłaszcza te z Wielkiego Piątku, kiedy przyciskał tak mocno krzyż Jezusa, albo z wielkanocnej modlitwy Regina caeli, kiedy nie mógł już wydobyć ani jednego słowa. Jan Paweł II pokazał swoim życiem, że cierpienie to nie jest cel. Jakże wymowne są pod tym względem jego słowa, słowa schorowanego, cierpiącego człowieka, który pod koniec swojego życia pisał: „mimo ograniczeń mego wieku bardzo wysoko cenię sobie życie i umiem się

32 Jan Paweł II, List apost. poświęcony środkom społecznego przekazu Szybki rozwój, 24 stycznia 2005, nr 12.

${ }^{33}$ Metr od świętości, odc. 30 Wyznanie, program w TVP 1, 26.04.2014, godz. 16.45-17.00. 
nim cieszyć. Dziękuję za to Bogu. [...] Zarazem jednak głębokim pokojem napełnia mnie myśl o chwili, w której Bóg wezwie mnie do siebie - z życia do życia”34.

\section{Zakończenie}

$\mathrm{Na}$ koniec warto pokazać ostatnią odsłonę świętości: świętość jako przejście z życia do Życia. Jest to najtrudniejsza do medialnego pokazania odsłona świętości. To jest piękno życia wiecznego w perspektywie wiary. Dotykamy w tej odsłonie, np. w programie Santo Subito, samej istoty świętości i kultu ludzi świętych. Dotykamy istoty piękna życia ludzkiego, w które wpisane jest także przemijanie. Takie świadectwo Jana Pawła pozostawiło w nas przekonanie, że trzeba się zatrzymać nad życiem, dostrzegać jego piękno, bo przemijanie także ma sens, jak napisał papież w Tryptyku rzymskim ${ }^{35}$ i co pokazał swoim pięknym człowieczeństwem i pięknym życiem na wszystkich jego etapach.

"Święci nie przemijają, święci żyją świętymi, święci wołają o świętość”36. To jest wymiar świętości, jaki nam zostawił Jan Paweł II, świętości dobrego człowieka i wielkości autorytetu, pokazującego i broniącego godności każdego człowieka. Niech jego świętość przenika nas i promieniuje na nas, byśmy w sobie i w innych kształtowali piękno człowieczeństwa.

\section{Abstract}

\section{John Paul II - views the beauty of holiness}

Conserving the beauty of humanity was the primary concern of John Paul II, concern visualized in his poetic and dramatic, in his works of philosophy and ethics, but most of all in his beautiful life, in his ministry and teaching. This article is an attempt to show the holiness of John Paul II through the prism of his beautiful humanity. I'm trying to explore some of the views of holiness of John Paul II, in which he appears as a spiritual authority, as a man of hope, a good man, as a man of dialogue, etc. These images reveal the beauty and value of human life in the context of a beautiful spiritual values, which make up the dimension of holiness.

Ks. Michał Drożdż, Jan Paweł II - odsłony piękna świętości, [w:] Twarze świętości, red. Katarzyna Dybeł, Zofia Zarębianka, Kraków 2016, s. 45-58 (Dni Jana Pawła II).

http://dx.doi.org/10.15633/9788374385503.06

34 Jan Paweł II, List do ludzi w podeszłym wieku, Watykan 1999, nr 17.

35 Por. Jan Paweł II, Tryptyk rzymski. Medytacje, Kraków 2003, s. 10.

36 Jan Paweł II, Homilia w czasie Mszy św. odprawionej w Starym Sączu, Stary Sącz, 10 czerwca 1999 roku, nr 1. 